\title{
Erythrocyte potassium, sodium and glutathione concentrations and their relationship with reproduction, body weight and fleece weight traits in Awassi sheep
}

\begin{abstract}
Relationship between erythrocyte potassium $\left(\mathrm{K}_{\mathrm{e}}\right)$, erythrocyte sodium $\left(\mathrm{Na}_{\mathrm{e}}\right)$ and blood glutathione (GSH) concentrations and production/reproduction traits were investigated in Awassi sheep. Thirty healthy sheep subjected to analyze for phenotypic and gene frequencies of $\mathrm{K}_{\mathrm{e}}, \mathrm{Na}_{\mathrm{e}}$ and GSH concentrations. Correlation between these parameters and production/reproduction traits such as greasy fleece weight, milk production, birth rate, single and twin birth rate and body weight were calculated. A positive correlation was found between birth rate and mean $\mathrm{K}_{\mathrm{e}}$ concentration $(\mathrm{r}=0.481, \mathrm{P}<0.008)$ and $\mathrm{Na}_{\mathrm{e}}$ concentration $(\mathrm{r}=-0.454$, $\mathrm{P}<0.013)$. Another correlation between GSH concentration and greasy fleece weight $(r=-0.368, \mathrm{P}<0.049)$ and milk production $(r=0.379, \mathrm{P}<0.050)$ parameters was also evidenced. These suggest that $\mathrm{K}_{\mathrm{e}}, \mathrm{Na}_{\mathrm{e}}$ and $\mathrm{GSH}$ concentrations may be included in the metabolic profile testing parameters.
\end{abstract}

Keywords: Awassi sheep, erythrocyte potassium, erythrocyte sodium, glutathione, biochemical polymorphism, production traits, reproduction traits

\section{Zusammenfassung}

Titel der Arbeit: Zusammenhang zwischen Erythrozytenkalium, -natrium sowie Glutathionkonzentration und Reproduktionsmerkmalen, Gewicht und Wollcharakteristika bei Awassi-Schafen

Das Verhältnis zwischen den Erythrozytenkalium $\left(\mathrm{K}_{\mathrm{e}}\right)$, -natrium $\left(\mathrm{Na}_{\mathrm{e}}\right)$ sowie Blutwerten von Glutathion (GSH) und den Produktions- und Reproduktionsmerkmalen wurden bei Awassi-Schafen untersucht. Dreißig Tieren wurden Blutproben entnommen, um Korrelationen zwischen phenotypischen Eigenschaften und Genfrequenzen von $\mathrm{K}_{\mathrm{e}}, \mathrm{Na}_{\mathrm{e}}$ und $\mathrm{GSH}$ zu bestimmen. Korrelationen zwischen den genannten Blutparametern und Produktion- und Reproduktionsmerkmalen, wie Wollgewicht, Milchproduktion, Geburtsrate, Zwillingsrate und Körpergewicht, wurden errechnet. Eine positive Korrelation wurde zwischen Geburtsrate und mittlerer $\mathrm{K}_{\mathrm{e}}$-Konzentration $(\mathrm{r}=0.481, \mathrm{P}<0.008)$ und $\mathrm{Na}_{\mathrm{e}}$-Konzentration $(\mathrm{r}=-0.454, \mathrm{P}<0.013)$ festgestellt. Es wurde ebenfalls eine Korrelation zwischen GSH-Konzentration und Wollgewicht $(\mathrm{r}=-0.368, \mathrm{P}<0.049)$ sowie Milchproduktion $(r=0.379, \mathrm{P}<0.050)$ nachgewiesen. Diese Ergebnisse weisen darauf hin, dass die $\mathrm{K}_{\mathrm{e}}, \mathrm{Na}_{\mathrm{e}}$ und GSH-Konzentrationen eventuell als metabolische Testparameter verwendet werden können.

Schlüsselwörter: Awassi-Schafe, Erythrozytenkalium, Erythrozytennatrium, Glutathion, biochemischer Polymorphismus, Produktionsmerkmale, Reproduktionsmerkmale

\section{Introduction}

Awassi sheep constitute approximately $7 \%$ of sheep population in Turkey. This breed has high adaptation capability and is the unique sheep race with high milk capacity which is able to live in flocks (AKCAPINAR, 2000).

The relation between blood parameters and production/reproduction traits may be controlled by the same genes which is called "pleitrophic effect" of genes (AYALA and KIGER, 1980). Most animal cells maintain high internal potassium and low 
sodium ion concentration due to the activity of the sodium/potassium-ATPase (Na/K-ATPase) pump in the membrane, which uses energy derived from the hydrolysis of ATP to accumulate potassium ions and expel sodium ions. The enzyme ATPase is intimately involved in the potassium or sodium-pump mechanism (TUCKER, 1971). EVANS (1954) reported that erythrocyte potassium concentration varied in sheep and two distinct types could be found in British breed. The author demonstrated that some sheep have erythrocyte potassium values of $80-90 \mathrm{mmol} / \mathrm{L}$ (HK-type) while others have $20-30 \mathrm{mmol} / \mathrm{L}$ (LK-type). This difference is genetically controlled and the gene(s) determining the HK type being apparently dominant to LK type (TUCKER, 1971). It has been evidenced by several researchers that erythrocyte potassium and sodium concentrations in domestic animals are associated with some production/reproduction traits such as milk production, body weight, mortality rate, fleece weight, fertility and adaptation capacity (RASMUSEN et al., 1974; MULEI et al., 1988; TUCKER et al., 1973; ATROSHI, 1979; KRISHNAMURTHY et al., 1978; SENGUPTA, 1974; ANTUNOVIC et al., 2004; MILEWSKI and SZCZEPANSKI, 2006). The erythrocyte cell contains relatively large amount of GSH. GSH functions by protecting the protein-SH groups of enzymes, hemoglobin or membrane from oxidation (AGAR and BOARD, 1983). Glutathione peroxidase catalyzes the reduction of hydroperoxides, including hydrogen peroxide, by reduced glutathione and functions to protect the cell from oxidative damage. An integral component of the enzyme glutathione peroxidase is selenium. The physiological function and peroxidant role of this enzyme have been precisely determined (SZILAGYI et al., 1994; CASTILLO et al., 2001; KOLEDZIEJ et al., 2005). In some sheep breeds, levels of GSH show a distinct bimodal distribution and as potassium and sodium concentrations it is possible to divide animals into two groups according to their erythrocyte GSH concentrations. Sheep with GSH values below $55 \mathrm{mg} / 100 \mathrm{ml}$ erythrocyte are classified as GSH low type $\left(\mathrm{GSH}^{\mathrm{h}}\right)$ and those having higher concentration than this values are classified as GSH high type $\left(\mathrm{GSH}^{\mathrm{H}}\right)$ (ATROSHI, 1979). GSH concentration is regulated by a pair of autosomal alleles; however this genetic effect is modulated by environmental and some other genetic factors. (CASTILLO et al., 2001; SWIDERSKA-KOLACZ et al., 2001). Several studies have been conducted to find out correlations between GSH concentration and different production/reproduction parameters. Higher mortality (TUCKER et al., 1976) and lower body weight (ATROSHI, 1979) were reported for $\mathrm{GSH}^{\mathrm{h}}$ lambs. On the other hand, higher body weight gain (ATROSHI, 1979) and better milk production capacity (ATROSHI and SANDHOLM, 1982) were reported for $\mathrm{GSH}^{\mathrm{H}}$ ewes. Higher wool production capacity was also stated for Indian sheep having lower erythrocyte GSH concentration (KALLA and GHOSH, 1975).

Adaptation experiments of Awassi sheep, the unique race able to grow up in flocks, are actually carried out in our research center. Data obtained from the present work would be useful for the improvement of Awassi race since there are no detailed studies on the correlation of production/reproduction and biochemical polymorphism characters of this race. The variability of erythrocyte $\mathrm{K}$ and $\mathrm{Na}$ concentration and blood GSH level of Awassi sheep and their relationship with some productive/ reproductive traits were investigated. 


\section{Materials and methods}

Thirty Awassi sheep of sixteen month of age obtained from the "Animal Production, Research and Application Centre" of Uludag University, Faculty of Veterinary Medicine were used as research material. All procedures involving animals were approved by the Animal Care and Use Committee of Uludag University.

The sheep were fed free choice source of high quality clover hay with $300 \mathrm{~g}$ concentrate mixture. The concentrate mixture was composed from mainly whole barley $(70 \%)$, maize $(20 \%)$ and soybean meal (10\%) supplemented with mineral/vitamin combination. Blood samples were collected by jugular venipuncture directly into heparinized tubes. The hematocrit was determined by centrifuging the blood in heparinized capillary tubes in a microcapillary centrifuge (Nuve Laboratory Equipment, Ankara, Turkey) for $5 \mathrm{~min}$ at $13000 \times \mathrm{g}$ and a reader (International Equipment Co., Needham, MA, USA). After centrifugation at $3000 \times \mathrm{g}$ for 10 min (Hettich EBA 21 Centrifuge, GMI Inc., Minnesota, USA) the cellular fraction was separated from the plasma. The potassium and sodium concentrations in the whole blood and plasma were determined by flame photometry (PFP 7 Flame Photometer, Jenway Ltd., Essex, England) in 1:200 diluted samples by using the procedures explained by the manufacturer's instructions. Erythrocyte potassium and sodium concentrations were calculated using whole blood and plasma values of these electrolytes. Hematocrit values were assessed by using the following formula (GONZALEZ et al., 1984):

$$
X e=X p+[(X w b-X p) /(P C V: 100)]
$$

where: $X=$ sodium or potassium, $X p=$ concentration of cation in plasma, $X w b=$ concentration of cation in whole blood, $X e=$ Concentration of cation in erythrocyte, $P C V=$ Hematocrit.

The (LK) allele frequencies were calculated from the square root of the percentage of (HK) phenotype animals (SOYSAL et al., 2005). The level of reduced GSH in erythrocytes was determined by the method of BEUTLER (1971). Erythrocyte was firstly deproteinated by addition of trichloroacetic acid (TCA) and centrifuged (10 $\min , 3000 \mathrm{~g} / \mathrm{min}$ ). Thereafter, DTNB [5, 5'-dithiobis (2-nitrobenzoic acid)] was added into the supernatant and the formation of 5-thio-2-nitrobenzoic acid, which is proportional to total glutathione concentration, was monitored at $412 \mathrm{~nm}$ at $25^{\circ} \mathrm{C}$ against reagent controls.

Shearing process was performed in the $16^{\text {th }}$ month of age by means of shearing machine (Oster Professional Products, McMinnville, TN, USA). The animals were weighed at the beginning of insemination period (18 months of age). Parturition was towards the end of second age. The ewes were milked twice a day and individual milk production was recorded bi-weekly. When daily milk yield per ewe decreased to $200 \mathrm{ml}$ (approximately 150 days) the animals were dried off (ICAR, 1992). Total milk production was estimated according to THOMAS et al. (2001).

\section{Statistical analysis}

Correlations between high and low type erythrocyte potassium, sodium, glutathione groups and other traits were analyzed with pair wise correlation analysis. All statistical analyses were carried out with Minitab version 12 statistical software (MINITAB 12, 1998). 


\section{Results}

Data regarding to erythrocyte potassium, sodium and glutathione levels, their types, phenotypic and gene frequencies of Awassi sheep are presented Table 1. Individuals having erythrocyte potassium concentration below or equal to $50 \mathrm{mEq} / \mathrm{L}$ were grouped as LK whereas those having higher than this value were grouped as HK. The overall range of $\mathrm{K}_{\mathrm{e}}$ and $\mathrm{Na}_{\mathrm{e}}$ concentrations were 10.62-105.83 and 34.00-126.00 mmol/1, respectively. As it can be seen from the table, both of $\mathrm{K}_{\mathrm{e}}$ and $\mathrm{Na}_{\mathrm{e}}$ concentration exhibited a bimodal distribution, nonetheless $\mathrm{HK}$ and $\mathrm{HNa}$ animals were predominant.

Erythrocyte GSH values ranged between $13.05-75.67 \mathrm{mg} / 100 \mathrm{ml}$ with a mean of $41.70 \pm 3.36 \mathrm{mg} / 100 \mathrm{ml}$. According to these results we classified the animals as GSH-low type $\left(\mathrm{GSH}^{\mathrm{h}} \leq 50 \mathrm{mg} / 100 \mathrm{ml}\right)$ and $\mathrm{GSH}$-high type $\left(\mathrm{GSH}^{\mathrm{H}}>50 \mathrm{mg} / 100 \mathrm{ml}\right)$. A bimodal distribution was also noted for this parameter even a significant proportion of individuals were $\mathrm{GSH}^{\mathrm{h}}$.

Table 1

Distribution of erythrocyte potassium, sodium and glutathione groups and their phenotypic and gene frequencies in Awassi sheep (Verteilung von Erythrozytenkalium, -natrium und Glutathiongruppen und deren Phänotypen und Genfrequenzen bei Awassi-Schafen)

\begin{tabular}{lrrrcc}
\hline Genotype & $\mathrm{n}$ & Distribution values & Mean \pm SEM & $\begin{array}{c}\text { Phenotypic } \\
\text { frequency }\end{array}$ & $\begin{array}{c}\text { Gene } \\
\text { frequency }\end{array}$ \\
\hline $\mathrm{K}_{\mathrm{e}}(\mathrm{mmol} / \mathrm{l})$ & 30 & $10.62-105.83$ & $73.43 \pm 5.10$ & - & - \\
$\mathrm{LK}(\mathrm{mmol} / \mathrm{l})$ & 6 & $10.62-30.24$ & $23.91 \pm 3.04$ & 0.20 & 0.447 \\
$\mathrm{HK}(\mathrm{mmol} / \mathrm{l})$ & 24 & $64.04-105.83$ & $85.81 \pm 2.69$ & 0.80 & 0.894 \\
$\mathrm{Na}(\mathrm{mmol} / \mathrm{l})$ & 30 & $34.00-126.00$ & $74.05 \pm 4.14$ & - & - \\
$\mathrm{LNa}(\mathrm{mmol} / \mathrm{l})$ & 4 & $34.00-47.25$ & $43.34 \pm 3.12$ & 0.13 & 0.36 \\
$\mathrm{HNa}(\mathrm{mmol} / \mathrm{l})$ & 26 & $50.67-126.00$ & $78.78 \pm 4.01$ & 0.86 & 0.93 \\
$\mathrm{GSH}(\mathrm{mg} / 100 \mathrm{ml}$ erythrocyte$)$ & 30 & $13.05-75.67$ & $41.70 \pm 3.36$ & - & - \\
$\mathrm{GSH}(\mathrm{mg} / 100 \mathrm{ml}$ erythrocyte) & 21 & $13.05-46.32$ & $31.80 \pm 2.40$ & 0.70 & 0.836 \\
$\mathrm{GSH}^{\mathrm{H}}(\mathrm{mg} / 100 \mathrm{ml}$ erythrocyte$)$ & 9 & $54.27-75.67$ & $64.79 \pm 2.83$ & 0.30 & 0.547 \\
\hline $\mathrm{K}_{\mathrm{c}}$ & 9 &
\end{tabular}

$\mathrm{K}_{\mathrm{e}}=$ erythrocyte potassium; $\mathrm{LK}=$ low potassium; $\mathrm{HK}=$ high potassium; $\mathrm{Na}_{\mathrm{e}}=$ erythrocyte sodium; LNa $=$ low sodium; $\mathrm{HNa}=$ high sodium; $\mathrm{GSH}=$ glutathione; $\mathrm{GSH}^{\mathrm{h}}=$ low glutathione; $\mathrm{GSH}^{\mathrm{H}}=$ high glutathione

Some productive/reproductive traits such as fleece yield, milk yield, reproductive efficiency parameters and body weights of sheep having with low and high $\mathrm{K}_{\mathrm{e}}, \mathrm{Na}_{\mathrm{e}}$ and GSH values are presented in Table 2. Correlations between these parameters are shown in Table 3.

Table 2

Productive/reproductive traits and $\mathrm{K}_{\mathrm{e}}, \mathrm{Na}_{\mathrm{e}}$ and $\mathrm{GSH}$ groups of Awassi sheep

(Produktions- und Reproduktionsmerkmale sowie $\mathrm{K}_{\mathrm{e}}, \mathrm{Na}_{\mathrm{e}}$, GSH-Gruppen der Awassi-Schafe)

\begin{tabular}{|c|c|c|c|c|c|c|}
\hline Genotype & $\begin{array}{c}\text { Greasy fleece } \\
\text { weight (kg) }\end{array}$ & $\begin{array}{l}\text { Milk yield } \\
(\mathrm{kg})\end{array}$ & Fertility (\%) & $\begin{array}{l}\text { Single birth } \\
\text { rate }(\%)\end{array}$ & $\begin{array}{l}\text { Twin birth } \\
\text { rate }(\%)\end{array}$ & $\begin{array}{c}\text { Body weight } \\
(\mathrm{kg})\end{array}$ \\
\hline $\mathrm{LK}(\mathrm{mmol} / \mathrm{l})$ & $4.9 \pm 0.4$ & $134.4 \pm 3.6^{\mathrm{a}}$ & 67 & 75 & 25 & $66.8 \pm 4.3$ \\
\hline $\mathrm{HK}(\mathrm{mmol} / \mathrm{l})$ & $5.2 \pm 0.2$ & $112.1 \pm 7.5^{\mathrm{b}}$ & 100 & 48 & 52 & $64.5 \pm 1.4$ \\
\hline $\mathrm{LNa}(\mathrm{mmol} / \mathrm{l})$ & $5.3 \pm 0.3$ & $85.0 \pm 19^{c}$ & 100 & 75 & 25 & $69.5 \pm 3.1$ \\
\hline $\mathrm{HNa}(\mathrm{mmol} / \mathrm{l})$ & $5.1 \pm 0.2$ & $120.1 \pm 7.9^{d}$ & 92 & 43 & 57 & $64.2 \pm 1.5$ \\
\hline $\begin{array}{l}\mathrm{GSH}^{\mathrm{h}}(\mathrm{mg} / 100 \mathrm{ml} \\
\text { erythrocyte })\end{array}$ & $5.3 \pm 0.2$ & $111.5 \pm 8.4$ & 95 & 50 & 50 & $65.9 \pm 2.9$ \\
\hline $\begin{array}{l}\mathrm{GSH}^{\mathrm{H}}(\mathrm{mg} / 100 \mathrm{ml} \\
\text { erythrocyte })\end{array}$ & $4.6 \pm 0.3$ & $123.4 \pm 17$ & 88 & 57 & 43 & $64.5 \pm 1.6$ \\
\hline
\end{tabular}

LK = low potassium; $\mathrm{HK}=$ high potassium; $\mathrm{LNa}=$ low sodium; $\mathrm{HNa}=$ high sodium; $\mathrm{GSH}^{\mathrm{h}}=$ low glutathione; $\mathrm{GSH}^{\mathrm{H}}=\mathrm{high}$ glutathione $\mathrm{a}, \mathrm{b}=$ means in the same column with different superscripts were different $(\mathrm{p}<0.05) ; \mathrm{c}, \mathrm{d}=$ means in the same column with different superscripts were different $(\mathrm{p}<0.05)$ 
Table 3

The correlation coefficients $(\mathrm{r})$ between $\mathrm{K}_{\mathrm{e}}, \mathrm{Na}_{\mathrm{e}}$ and GSH groups and productive/ reproductive traits (Korrelationskoeffizienten [r] zwischen $\mathrm{K}_{\mathrm{e}}, \mathrm{Na}_{\mathrm{e}}$, GSH-Gruppen und den Reproduktionsmerkmalen)

\begin{tabular}{lcrrr}
\hline Genotype & $\begin{array}{c}\text { Greasy fleece } \\
\text { weight }\end{array}$ & Milk yield & Birth rate & Body weight \\
\hline $\mathrm{K}_{\mathrm{e}}(\mathrm{mmol} / \mathrm{l})$ & 0.105 & -0.031 & $0.481^{* *}$ & -0.069 \\
$\mathrm{LK}(\mathrm{mmol} / \mathrm{l})$ & 0.586 & -0.253 & 0.178 & 0.718 \\
$\mathrm{HK}(\mathrm{mmol} / \mathrm{l})$ & -0.169 & 0.011 & -0.228 & 0.054 \\
$\mathrm{Na}(\mathrm{mmol} / \mathrm{l})$ & -0.155 & 0.189 & $-0.454^{*}$ & -0.022 \\
$\mathrm{LNa}(\mathrm{mmol} / \mathrm{l})$ & $0.955^{*}$ & 0.891 & 0.574 & 0.748 \\
$\mathrm{HNa}(\mathrm{mmol} / \mathrm{l})$ & -0.150 & 0.168 & $-0.437^{*}$ & 0.152 \\
$\mathrm{GSH}(\mathrm{mg} / 100 \mathrm{ml}$ erythrocyte $)$ & $-0.368^{*}$ & $0.379^{*}$ & -0.269 & 0.148 \\
$\mathrm{GSH}^{\mathrm{h}}(\mathrm{mg} / 100 \mathrm{ml}$ erythrocyte & -0.011 & 0.358 & 0.014 & 0.125 \\
$\mathrm{GSH}^{\mathrm{H}}(\mathrm{mg} / 100 \mathrm{ml}$ erythrocyte & 0.714 & 0.596 & -0.400 & 0.200 \\
\hline
\end{tabular}

${ }^{*} \mathrm{P}<0.05,{ }^{* *} \mathrm{P}<0.01$

$\mathrm{K}_{\mathrm{e}}$ values positively affected parturition rate $(\mathrm{r}=0.481, \mathrm{P}<0.01)$ whereas this parameter was negatively influenced from $\mathrm{Na}_{\mathrm{e}}$ concentration $(\mathrm{r}=-0.454, \mathrm{P}<0.05)$. Furthermore, greasy fleece weight was negatively influenced from GSH concentration $(\mathrm{r}=-0.368$, $\mathrm{P}<0.049$ ). A positive correlation was also calculated between milk yield and GSH concentration $(\mathrm{r}=0.379, \mathrm{P}<0.05)$.

\section{Discussion}

The potassium, sodium and GSH concentrations of mammalian erythrocytes and their regulation constitute characteristics specific to these cells and also a consequence of their high specialization. Electrolyte polymorphism studies were undertaken for several animal species. (SZILAGYI et al., 1994; SWIDERSKA-KOLACZ, 2001; BARANOWSKI et al., 2004; KOLEDZIEJ and JACYNO, 2005). Polymorphism of erythrocyte potassium content was first described in sheep (EVANS, 1954). A pair of alleles replaced at one locus was proposed as being the cause of such variation, the gene for HK behaving as if dominant over that for LK type. Polymorphic cells allowed the establishment of pattern of ionic and volume regulation in erythrocytes. It has been reported that cation pump transfers one sodium ion from outside the cell, but the pump works four times faster than in the HK cell. Also HK cells are relatively permeable to sodium compared to potassium than are LK cells and sodium exchange diffusion is more rapid in LK than in HK animals (TUCKER, 1971). Moreover, strongly evidenced that ATPase activity is involved in the potassium pump mechanism and the activity of this enzyme is 3-4 times greater in HK than LK membranes (TOSTESON, 1963). In LK group animals, positive correlation between levels of ATP and potassium is exist (EATON et al., 1967). LK cells are the consequence of low active cation-transport and high passive membrane permeability; whereas the HK cells display reverse of this behavior (TOSTESON and HOFFMAN, 1960).

EVANS (1957) suggested four distinct groups named $\mathrm{K}_{\mathrm{e} \gamma}, \mathrm{K}_{\mathrm{e} \alpha}, \mathrm{K}_{\mathrm{e} \lambda}$ and $\mathrm{K}_{\mathrm{e} \delta}$ of sheep that can be distinguished as to their erythrocyte $\mathrm{K}$ concentrations plotted against erythrocyte $\mathrm{Na}$ concentrations. $\mathrm{K}_{\mathrm{e} \delta}$-type sheep are apparently quite rare, but relatively common in Awassi sheep in Israel (EVANS, 1966).

A correlation between erythrocyte potassium and GSH type was evidenced for Finnish Landrace sheep and lower $\mathrm{K}_{\mathrm{e}}$ values were obtained with the lower GSH type 
animals (TUCKER and KILGOUR, 1973). Our findings are not in agreement with these findings but parallel to other study performed with $\mathrm{K}_{\mathrm{e} \delta}$-type Awassi sheep having HK, GSH ${ }^{\mathrm{h}}$ type erythrocytes (TUCKER and KILGOUR, 1970).

In the present study, Awassi sheep were classified as high and low $\mathrm{Na}_{\mathrm{e}}, \mathrm{K}_{\mathrm{e}}$ and $\mathrm{GSH}$ types. Distribution of $\mathrm{K}_{\mathrm{e}}$ concentrations is similar to previous results obtained for Awassi sheep (EVANS, 1955; EVANS, 1957) with individuals' falling into similarly HK and LK types. HK type was predominant for this race and we have found statistically important correlation with the birth rate and HK concentrations. Similar observations were reported for different sheep races (BARANOWSKI, 2002; ANTUNOVIC et al., 2004; MILEWSKI and SZCZEPANSKI, 2006). BHASKAR et al. (1978) and YATSENKO (1973) reported higher fertility rate for the Mandya and Kirgiz wool sheep respectively having higher $\mathrm{K}_{\mathrm{e}}$ concentrations. On the other hand, in a study performed on Black Bengal goats authors did not find correlation with reproductive traits and $\mathrm{K}_{\mathrm{e}}$ concentration (MANDAL et al., 1988).

Concentration of GSH has also important role on some productivity traits (CASTILLO et al., 2001; BALICKA-RAMICZ et al., 2006). In the present experiment, $\mathrm{GSH}^{\mathrm{H}}$ type Awassi sheep had higher milk production capacity and lower fleece weight. In contrast, milk production was reduced in $\mathrm{GSH}^{\mathrm{h}}$ type animals while fleece quantity was augmented. $\mathrm{GSH}^{\mathrm{h}}$ concentration seems to be caused by a defect in the amino acid uptake mechanism at the erythrocyte membrane (YOUNG and ELLORY, 1977). The hypothesis that GSH is involved in milk synthesis comes from the finding that the sheep with high GSH produce more milk than GSH $^{\mathrm{h}}$ sheep (ATROSHI and SANDHOLM, 1982). Glutathione concentration in erythrocytes may also be correlated with some other production/reproduction traits. For example MABON (1969) found that change in glutathione concentrations was related to feed efficiency in neonatal calves. Studies to find out correlation between GSH types and birth rate in sheep revealed that $\mathrm{GSH}^{\mathrm{H}}$ animals had higher birth rate and advantageous fleece weight compared to other group animals (MERT et al., 1987).

These findings could suggest that since some production/reproduction traits are correlated to $\mathrm{Na}_{\mathrm{e}}, \mathrm{K}_{\mathrm{e}}$ and $\mathrm{GSH}$ groups, selection of animals having superiorities for the desired characters may be done by taking into account these genetic polymorphic characters. Obtained results may be useful in the characterization and improvement of production and reproduction traits in Awassi sheep.

\footnotetext{
References

AGAR, N.S.; BOARD, P.G.:

Red cell metabolism, in: AGAR, N.S.; BOARD, P.G. (ed.), Red Blood Cells of Domestic Mammals, Amsterdam (1983), 227-252

AKÇAPINAR, H.: Sheep Breeding, $2^{\text {nd }}$ Ed., Ankara (2000), 108-117 [in Turkish]

ANTUNOVIC, Z.; SPERANDA, M.; STEINER, Z.:

The influence of age and the reproductive status to the blood indicators of the ewes. Arch. Tierz. 47 (2004), 265-273

ATROSHI, F.:

Pheotypic and genetic association between production/reproduction traits and biochemical polymorphic characters in Finn sheep. Thesis, Government Printing Centre, Helsinki (1979), 37-42

ATROSHI, F.; SANDHOLM, M.:

Red blood cell glutathione as a marker of milk production in Finn sheep. Research in Veterinary Science 33 (1982), 256-259

AYALA, F.J.; KIGER, J.A. Jr.:

Modern genetics. Menlo Park (1980)
} 
BALICKA-RAMICZ, A.; PILARCZYK, B.; RAMICZ, A.; WIECZOREK, M.:

Effect of selenium administration on blood serum Se content and on selected productive characteristics of sheep. Arch. Tierz. 49 (2006), 176-180

BARANOWSKI, P.:

Genetic and environmental factors of macroelements concentration in blood serum and osseous tissue of lambs in north-west Poland. Arch. Tierz. 45 (2002), 565-574

BARANOWSKI, P.; KLATA, W.; BARANOW-BARANOWSKI, S.:

Macroelements concentration in the osseous tissue of caudal vertebra in domestic sheep lambs and of mandibular bone of in roe deer bucks coming from the northern and southern region of Western Pomerania in Poland. Arch.Tierz. 47 (2004), 75-84

BEUTLER, E.: Red Cell Metabolism A. Manual of Biochemical Methods, New York (1971), 103

BHASKAR, B.; KRISHNAMURTHY, U.S.; RATHNASABAPATHY, V.: Blood potassium and their relationship writh production in sheep, Cherion 7 (1978), 22-27

CASTILlO, C.; HERNANDEZ, J.; LOPEZ-ALONSO, M.; MIRANDA, M.; BENEDITO, J.L.: A different point of view of glutathione peroxidase, its relationship to the metabolic changes associated with nutritional management in Assaf ovine breed. Arch. Tierz. 44 (2001), 305-312

EVANS, J.V.: Electrolyte concentration in red blood cells of British breeds of sheep, Nature 174 (1954), 931

EVANS, J.V; KING, J.W.:

Genetic control of sodium and potassium concentrations in the red blood cells of sheep. Nature $\mathbf{1 7 6}$ (1955), 171

EVANS, J.V.:

The stability of the potassium concentration in the erythrocytes of individual sheep compared with the variability between different sheep. The Journal of Physiology 136 (1957), 41-59

EVANS, J.V.:

Red cell electrolytes and haemoglobin, in: Proc. XI ${ }^{\text {th }}$ Cong. Inter. Soc. Haemotology, Sydney (1966), 278-293

GONZALEZ, P.; TUNON M.J.; DIAZ, M.; VALLEJO, M.:

Blood plasma and erythrocyte sodium concentrations of six Spanish cattle breeds. Anales de la Facultad de Veterinaria de Leon 30 (1984), 137-145

KOLODZIEJ, A.; JACYNO, E.:

Effect of selenium and vitamin E supplementation on reproductive performance of young boars. Arch. Tierz. 48 (2005), 68-75

ICAR:

International regulations for milk recording in sheep. International Committee for Animal Recording. Rome (1992)

KALLA, S.D.; GHOSH, P.K.:

Blood biochemical polymorphic traits in relation to wool production efficiency in Indian sheep. Journal of Agricultural Science 84 (1975), 149-52

KRISHNAMURTHY, U.B.; RATHNASABATHY, V.:

Genetic of blood potassium in Nilagiri, Merino and their crossbred sheep. 2. Potassium types and their relationship with production and reproduction traits. Indian Veterinary Journal 55 (1978), 962966

MABON, R.M.:

Erythrocyte glutathione and growth in the calf. British Veterinary Journal 125 (1969), 591-595

MANDAL, K.G.; SINHA, R.; MAITRA, O.; MISHRA, S:; DUTTAGUPTA, R.:

Blood potassium and sodium types in Black Bengal goats. Experimental Genetics 4 (1988), 4-9

MERT, N.; OĞAN, M.; TANRIVERDI, M.:

The Relationship with erythrocyte potassium types and production in Merino sheep. Uludag University Journal of the Faculty of Veterinary Medicine 1-2-3 (5-6) (1987), 23-27 [in Turkish, English abtract]

MILEWSKI, S.; SZCZEPANSKI, W.:

Effect of electromagnetic fields on the meat performance and wool performance of sheep. Arch.Tierz. 49 (2006), 219-225

MULEI, C.M.; DANIEL, R.C.; GREEN, D.:

Changes in erythrocyte $\mathrm{Mg}, \mathrm{Na}$ and $\mathrm{K}$ concentrations in late pregnancy and early lactation and their relationship with subsequent fertility and milk production in dairy cows. Zentralbl. Veterinärmed. A. 35 (1988), 522-528

RASMUSEN, B.A.; TUCKER, E.M.; ELLORY, J.C.; SPOONER, R.L.:

The relationship between $\mathrm{S}$ system of blood groups and potassium levels in red blood cells of cattle. Animal Blood Groups and Biochemical Genetics 5 (1974), 95-104 
SENGUPTA, B.P.:

Adaptive significance of red cell potassium types in buffaloes. Journal of Agricultural Sciences 82 (1974), 563-566

SOYSAL, M.I.; GURCAN, E.K.; KÖK, S.:

A Study of the distribution of potassium polymorphism in erythrocytes of Grey Cattle raised in the Edirne Province of Turkiye. Trakia Journal of Sciences 3 (2005), 8-10

SWIDERSKA-KOLACZ, G.; KOLOTAJ, A.; KLUSEK, J.:

The effect of the slaughter method, inbred, age and race on the glutathione levels in some organs of rabbits. Arch. Tierz. 44 (2001), 323-327

SZILAGYI, M.; SANKARI, S.; LINDBERG, P.; WITTMAN, M.:

Selenium status and serum biochemical parameters in halothane positive and negative pigs. Arch. Tierz. 37 (1994), 279-286

THOMAS, D.L.; BERGER, Y.M.; MCKUSICK, B.C.:

Effects of breed, management system, and nutrition on milk yield and milk composition of dairy sheep. J. Anim. Sci. 79 (2001), E16-E20

TOSTESON, D.C.; HOFFMAN, J.F.:

Regulation of cell volume by active cation transport in high and low potassium sheep red cells. The Journal of general physiology 44 (1960), 169-194

TUCKER, E.M.:

Genetic variation in the sheep red blood cell. Biological reviews of the Cambridge Philosophical Society 46 (1971), 341-86

TUCKER, E.M.; KILGOUR, L.:

An inherited glutathione deficiency and a concomitant reduction in potassium concentration in sheep red cells. Experientia 26 (1970), 203-204

TUCKER, E.M.; KILGOUR, L.:

The effect of anaemia on sheep with inherited differences in red cell reduced glutathione (GSH) concentrations. Res Vet Sci. 4 (1973), 306-311

TUCKER, E.M.; ELLORY, J.C.; KILGOUR, L.:

Determination of amino acid, cation and reduced glutathione levels in the red cells of Awassi sheep (Ovis aries). Comparative Biochemistry and Physiology 46 (1973), 103-107

TUCKER, E.M.; KILGOUR, L.; YOUNG, J.D.:

The genetic control of red cell glutathione deficiencies in Finnish Landrace and Tasmanian Merino sheep and in crosses between these breeds. Journal of Agricultural Science 87 (1976), 315-323

YATSENKO, V.D.:

Haemoglobin types and blood potassium levels in Kirgiz fine wool sheep and their relationship with reproduction. Institut zhivotnovodstva i- veterinarii 5 (1973), 52-54

YOUNG, J.D.; ELLORY, J.C.:

Red cell amino acid transport. In: ELLORY, J.C.; LEW, V.L. (Eds.): Membrane Transport in Red Cells. London (1977), 301-325 